\title{
p CORRESPONDENCE
}

\section{Enuresis}

R H Jackson, FRCP, and others; Frances $M$

Ulyatt, FFARCs; Susan D Dickson, $M B$, and

P Dickson, MB; Gwynne V Lewis, MRCs. . 95

Malaria in Wolverhampton

R G Thompson, MRCPATH, and others... . 952

Liver injury, drugs, and popular

poisons

J A W Wildsmith, FFARCS.

\author{
$\ldots \ldots .952$
}

Prescription for a better British diet

H M Sinclair, FRCP; H G Hanley, FRCS . . . 952

Labetalol and urinary metadrenalines

Pauline M Lax, BSC, and others......... 953

Difficulties in diagnosing meningococcal meningitis

V A Spagna, MD, and R B Prior, PHD . . . . . 953

Benign presentation of tuberculosis

meningitis

E M Grandjean, MD, and others....... 953

Premenstrual tension

U Halbreich, MD . .............. 954

Treatment of orthopaedic tuberculosis

D Ll Griffiths, Frcs.............. 954
Steroid treatment in giant cell arteritis

R J Harrison, FRCP............. 954

Drugs and breast-feeding

K H Kimbel, MD........

Cimetidine in acute upper

gastrointestinal bleeding

S M Z A Siddiqi, MRCP, and others..... 954

\section{Cimetidine and duodenal ulcer}

J R Bennett, FRCP . . . . . . . . . . . . . 955

Cimetidine overdosage

J B Wilson, MD................ 955

Peripheral skin necrosis complicating beta-blockade

P J Rees, MRCP

Drug-induced peripheral neuropathies A M Arnold, MRCP, and C J H Williams, MRCP $\ldots \ldots \ldots \ldots \ldots \ldots \ldots \ldots \ldots \ldots \ldots 95$

Vitamin $C$, disease, and surgical trauma

B D Vallance, MRCP and R Hulme, FRCPED 955

Back pain-what can we offer?

W A Mackey, FRCSED; R W Porter, FRCS. . . 956
Does adipocyte hypercellularity in obesity exist?

R T Jung, MRCP, and others........ 956

Health and safety at work

Gwen M Prentice, SRN . . . . . . . . . . 956

Service commitment and the training of surgeons

J J Shipman, FRCs, and others . . . . . . . . 957

College of anaesthetists?

P J F Baskett, FFARCs, and others. . . . . 957

Clinical medical officers in a child health service

J H Whittles, fFCM. . . . . . . . . . . . . 957

Pay-beds and the NHS

Isobel P Beswick, FRCPATH, and others. . . 957

Points Anaesthetic deaths ( $\mathbb{W}$ D Nickalls); Shortening hospital stay for psychiatric care (E H Bennie); Epilepsy and learning (Ruth F Harris); Brain failure in private and public life (P J M Davis); Immersion injury and frostbite (P J McDonald); Osteoarthritis (D R Sweetnam); Euthanasia (M J Pleydell); Some new titles (I Friedmann); ABC of ophthalmology (E Glucksman)........ 958
We may return unduly long letters to the author for shortening so that we can offer readers as wide a selection as possible. We receive so many letters each week that we have to omit some of them. Letters must be signed personally by all their authors. We cannot acknowledge their receipt unless a stamped addressed envelope or an international reply coupon is enclosed.

\section{Enuresis}

SIR,-We thoroughly agree with the comments in your leading article (17 March, p 705) about the inadvisability of treating enuresis in young children with tricyclic antidepressants, and have ourselves seen children poisoned by having taken their own or other siblings' drugs. We also agree that it is probably safer for tablets to be prescribed rather than medicine, but are very disappointed to see that the recommendation made by $\operatorname{Dr} \mathrm{A} J$ Cronin and others ( $p$ 722)-that these tablets should be dispensed in child-resistant containers-is not mentioned.

It is high time that all drugs which are potentially harmful to children are dispensed in these containers, which are highly effective. Regulations about their use under these circumstances are urgently needed. Meanwhile children die.

\section{Children's Department,}

Royal Victoria Infirmary,
Newcastle upon Tyne NE1 4LP

R H JACKSOR: A W CRAFT

Llandough Hospital,
Penarth, South Glam

J R SIBERT

SIR, - The statistics of bed-wetting quoted in your leading article (17 March, p 705), and in the article by Dr A J Cronin and others ( $p$ 722) to which it refers are much more optimistic than those which may be deduced from some other writers. Sears, Jacoby, and Levin ${ }^{1}$ indicate that about $20 \%$ of the 5-to 6-year-old group which they studied still wet the bed, and
Newson and Newson in their cohort study ${ }^{2}$ found that $27 \%$ of 4 -year-olds were still wet occasionally. This information was collected by social scientists. Since people admit embarrassing truths more readily to doctors these figures are probably an underestimate. Casual discussion suggests that as many as one child in four of primary school age may be wet often enough for the parents to be concerned.

In an age of washing machines and easy-care fabrics bed-wetting causes a parent less extra work than untidy eating habits, which are widely tolerated. In a period when the most bizarre details of sexual practice are a subject for conversation the embarrassment caused by bed-wetting, which seems to have become the last focus of irrational guilt and apprehension, seems almost inexplicable. The demand for treatment of 4-year-olds for a condition that is not pathological arises from a sort of conspiracy of silence which leads too many parents to have too high expectations. When these are disturbed by even a few wet beds their wrath, alarm, and despondency is a measure of their fear that their child will prove one of the minority who are enuretic.

Perhaps the first step to reduce parents' anxiety, and so to place their children at less risk, would be more realistic statistics in popular books on child rearing. A second would be to accept the idea that all children are wet occasionally and to present statistics in such a way as to draw attention to the increase with age of the probable intervals between wettings. This would be less frightening than the usual method, which sharply divides children at different ages into those who are dry and an unfortunate group which is wet, and might favour an atmosphere which would enable reliable information to be collected.

Frances Margaret Ulyatt

London SE27

${ }^{1}$ Sears, R R, Maccoby, E E, and Levin, H, Patterns of Child Rearing, $\mathrm{p} 131$. Illinois, Evanston, 1957. Child Rearing, p 131. Illinois, Evanston, 1957.
Urban, Comm anity, p 339. London, Allen and Urban Community, p 339. London, Allen and
Unwin, 1968.

SIR,-With regard to the recent leading article (17 March, $p$ 705) and paper on this subject by Dr A J Cronin and others (p 722), we are prepared to accept that the tricyclic antidepressants are commonly involved in childhood "accidental ingestion," but you do not seem to take into account the fact that these agents are more frequently prescribed for adults than for children.

We agree that buzzer treatment is at present the most effective cure for bed-wetting; nevertheless it is not suitable for all children. In particular, its use is limited in the under-7 age group because of the high failure rate. In some social situations buzzer use is not practicable, and, of course, with resources as deficient as they are there can be few parts of the country where there is not a waiting list of many months for the use of buzzers. In addition, buzzer treatment is complicated, and for success needs a high degree of parental and child co-operation and close supervision by qualified staff. None of these facts are mentioned in your articles.

We find that there are many situations in which tricyclic treatment can be useful, for instance in 6-7-year-old bed-wetters, and also for daytime enuresis. It is simply not true to say that under-8-year-olds are not concerned about their wetting. We all too often see younger children distressed by their position as social outcasts at school and within the 